\title{
Urdimento
}

Revista de Estudos em Artes Cênicas

E-ISSN: 2358.6958

\section{Carta-artigo para um ator aprisionado}

Zeca Nosé

\section{Para citar este artigo:}

NOSÉ, Zeca. Carta-artigo para um ator aprisionado.

Urdimento, Florianópolis, v. 3, n. 39, nov./dez. 2020.

DOI: http:/dx.doi.org/10.5965/14145731033920200107

Este artigo passou pelo Plagiarism Detection Software | iThenticate 


\title{
Carta-artigo para um ator aprisionado
}

Zeca Nosé

\begin{abstract}
Resumo
Este artigo é escrito em formato de carta, endereçada para o ator Bruno Araújo, integrante do grupo Confraria da Serra sediado na Penitenciária de Serra Azul I. O grupo é coordenado por Magno Bucci, que além deste, desenvolve atividades artísticas com o grupo Mulheres de Atenas, na Penitenciária Feminina de Ribeirão Preto. Ao longo da carta-artigo propomos a diferenciação de dois formatos de práticas teatrais que ocorrem dentro da prisão: Teatro entre Presos e Teatro com Presos. Por fim, apresentamos algumas experiências desenvolvidas por Bucci com pessoas aprisionadas e buscamos valorizar a importância artística dos eventos teatrais realizados na prisão, tanto para os atores, como para os espectadores.
\end{abstract}

Palavras-chave: Carta-Artigo. Teatro na prisão. Teatro entre Presos. Teatro com Presos.

\section{Letter-article for an imprisoned actor}

\begin{abstract}
This article is written in the form of a letter, addressed the actor Bruno Araújo, a member of the Confraria da Serra group based at the Serra Azul I Penitentiary. The group is coordinated by Magno Bucci, who also, develops artistic activities with the group Mulheres de Atenas, at the Ribeirão Preto Women's Penitentiary. Throughout the letter-article, we propose the differentiation of two forms of theatrical practice that take place inside the prison: Theater between Prisoners and Theater with Prisoners. Finally, we present some experiences developed by Bucci with prisoners, and we seek to value the artistic importance of theatrical events held in prison, both for the actors and the spectators.
\end{abstract}

Keywords: Letter-Article. Theater in prison. Theater between prisoners. Theater with prisoner's.

1 Diretor de Teatro e professor da Universidade Federal do Amapá. Doutorando em Artes da Cena na Universidade Estadual de Campinas (UNICAMP). Nome completo do autor: José Flávio Cardoso Nosé. jfzecanose@gmail.com 


\section{Carta-artículo para un actor preso}

\section{Resumen}

Este artículo es escrito en formato carta, dirigido al actor Bruno Araújo, integrante del grupo Confraria da Serra con sede en la Penitenciaría Serra Azul I. El grupo es coordinado por Magno Bucci, quien además de esto, desarrolla actividades artísticas con el grupo Mulheres de Atenas, en la Penitenciaría de Mujeres de Ribeirão Preto. A lo largo de la carta-artículo proponemos la diferenciación de dos formatos de prácticas teatrales que se desarrollan dentro de la prisión: Teatro entre Prisioneros y Teatro con Prisioneros. Al fin, presentamos algunas experiencias desarrolladas por Bucci con las personas encarceladas y buscamos valorar la importancia artística de los eventos teatrales que se realizan en prisión, tanto para los actores como para los espectadores.

Palabras clave: Carta-Artículo. Teatro en prisión. Teatro entre prisioneros. Teatro con prisioneros. 
Figura 1 - Desenho Prometeu acorrentado, Bruno Araújo, 2020

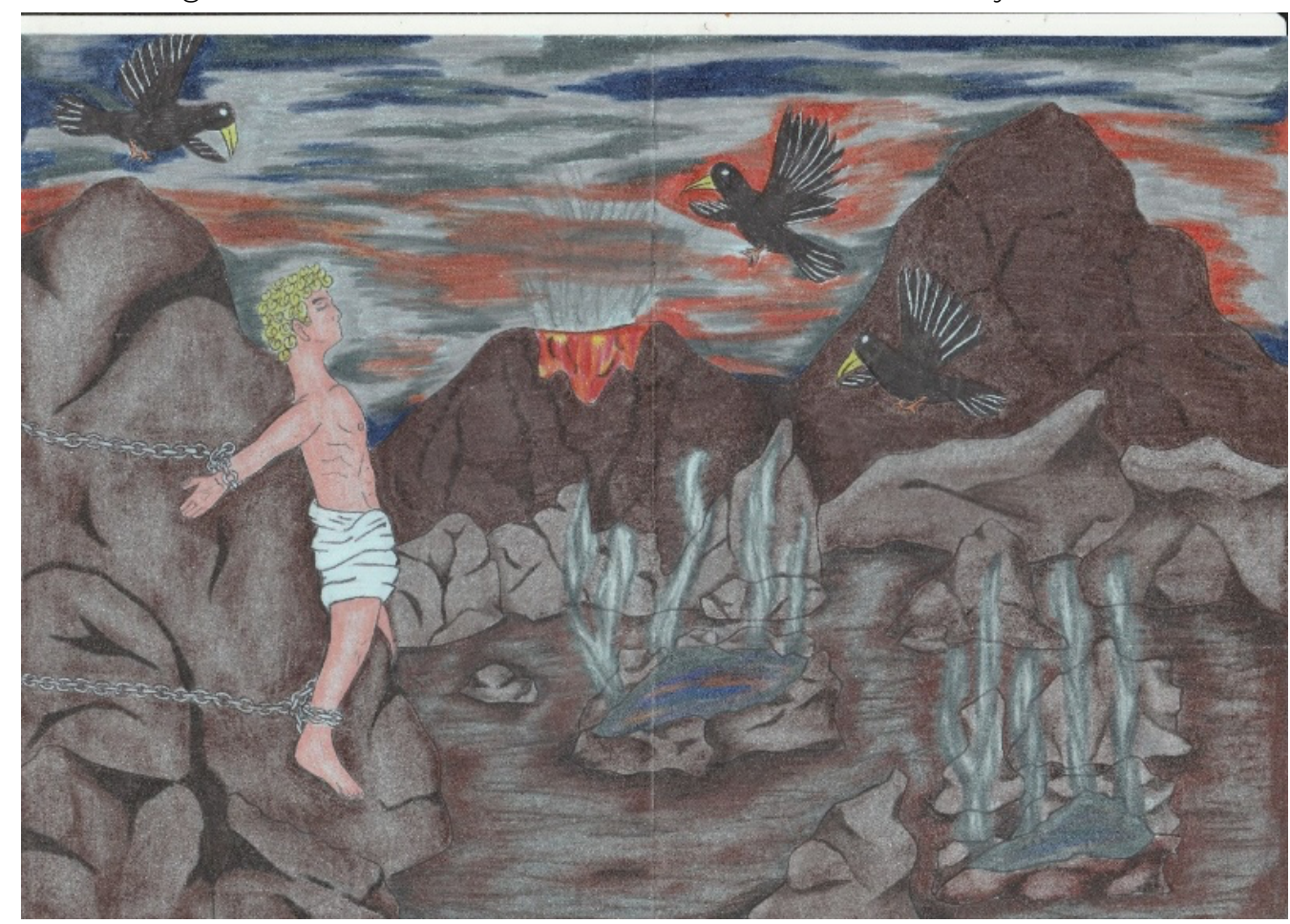

Fonte: Arquivo pessoal Zeca Nosé

Laguna, 20 de setembro de 2020

Mesmo quando eu andar por um vale de trevas e morte, não temerei perigo algum, pois tu estás comigo;

a tua vara e o teu cajado me protegem

Caro Bruno², como estão as coisas? Espero que minhas palavras te encontrem bem e com saúde. Manda um abraço para todos aí, que vocês tenham força para superar este momento de tanta adversidade. Não tenho como agradecer o desenho, você deu toda uma visão especial para a tragédia do Prometeu (Imagem

${ }^{2} \mathrm{O}$ uso dos nomes dos atores e imagens foram devidamente autorizados em Termo de Consentimento Livre e Esclarecido que se encontra arquivado com o pesquisador. 
01), já mandei uma foto para o Magno $^{3}$ e ele adorou! Vou enquadrar e colocar na parede, quando você vier nos visitar vai encontrá-lo em um lugar de destaque aqui em casa.

Bruno, esta carta vai ser um pouco diferente das outras, porque vou tentar publicá-la em uma revista científica chamada Urdimento. Eu estava tentando escrever um artigo para lá há algum tempo, e tudo o que produzia parecia vazio; era como se eu não conseguisse traduzir em palavras a potência da experiência de vocês aí no presídio de Serra Azul I. Quando fui responder sua última carta, percebi que as palavras vinham mais espontâneas se direcionadas a você, espero que não te incomode ser meu interlocutor neste caso.

Acredito que um artigo em formato de carta faz sentido quando voltamos nossa atenção às experiências teatrais que ocorrem dentro da prisão, por ser esta uma das principais formas de comunicação de quem está preso com o mundo exterior, ainda mais agora, com as visitas suspensas durante a pandemia.

Por ser uma carta-artigo, eu vou falar somente sobre minha pesquisa, e não vou abordar outros temas. Se for possível, mostra para os outros atores do grupo. Quase todos estavam curiosos sobre o que eu ia escrever, e aqui tem uma parte dos caminhos que segui na pesquisa. Eu gostaria muito de saber o que vocês acham das considerações que faço, e principalmente se consigo descrever com fidelidade as ações teatrais realizadas aí em Serra Azul I.

A entrevista do Leandro Pereira, que fez A Viagem do Chico com você, abriu todo um campo de investigação para mim. Ele me contou que já tinha feito quatro espetáculos na cadeia, antes de entrar no grupo Confraria da Serra: O Bom samaritano; Rei David; O cego de Jericó e Lazaro. Por ser religioso, o Leandro morava no "barraco" ${ }^{4}$ dos evangélicos no raio cinco, e o pastor sugeriu fazer as peças durante os cultos que aconteciam no pátio.

Feito por nós mesmo, sem eles [os outros presos] saberem de nada. Do nada eles viram ali, acontecendo, [...] eu acredito que se tiver alguém lá

\footnotetext{
${ }^{3}$ Magno Bucci, diretor dos grupos de teatro Mulheres de Atenas e Confraria da Serra, o primeiro sediado na Penitenciaria Feminina de Ribeirão Preto e o segundo no Presídio Masculino de Serra Azul I.

${ }^{4}$ Barraco é uma das denominações usadas pelos presos para se referir à cela.
} 
no raio do pavilhão cinco, eles não esqueceram mais. [...] A gente pegou e fez! Pegou um rapaz, pegamos uma pessoa que ia saber falar bem a parte de memória, de mente, [...] teve um treinamento dentro da igreja, que é o ensaio. [...] É impressionante, porque lá no fundo tem o corredor, aí tinha aquela multidão. Antes de entrar Jesus para dialogar com resto da lei. Aí ele tá lá no fundão... ninguém tá vendo... tá vendo só que o cara está se amarrando de roupa de lençol. Porque nós não temos como fazer um vestido. Nós fizemos com um lençol lá. Fizemos umas amarrações, enrolamos o sacerdote tudo. Fizemos tipo um caracol, [...] e o rapaz ainda era mais escurinho, ficou engraçado. E a população vendo: o que este rapaz está aprontando? Daqui a pouco - as pessoas no culto - o corredor no meio, aí a gente vinha com Jesus assim [gesto de prece com as mãos], mestre, rabi, senhor, Jesus, filho de Deus, e tal... aquela gritaria! E as pessoas começaram a olhar, o que está acontecendo? [...]. (Pereira, 2020).

Quando o Leandro falou que as peças foram feitas "por nós mesmos", entendi que o "nós" são vocês; e eu, ou qualquer outra pessoa que nunca foi presa, não fazemos parte deste "nós". Por isto, estou usando a expressão Teatro entre $^{5}$ Presos para me referir às experiências teatrais feitas na prisão, sem a participação de pessoas externas ao ambiente prisional.

Mas, é difícil encontrar outras experiências com este formato, porque só quem fez ou assistiu sabe sobre elas. Consegui localizar algumas através de livros, reportagens e estudos acadêmicos sobre pessoas que estiveram na prisão. O registro mais antigo que tomei conhecimento é de uma peça feita em 1936, descrita por Graciliano Ramos em Memórias do Cárcere $^{6}$, livro que conta o período em que o autor esteve preso. Uma das cadeias para onde Graciliano foi enviado se chamava Colônia Penal Cândido Mendes, conhecida como "Caldeirão do Diabo". Já ouviu falar desta prisão? Ela ficava na Itha Grande, em Angra dos Reis, no estado do Rio de Janeiro. Era tipo Alcatraz , porque ficava em uma ilha, mas já não funciona mais, foi fechada em 1994.

\footnotetext{
${ }^{5}$ Mesmo com abordagens distintas, as pesquisas desenvolvidas pela professora Márcia Pompeo Nogueira ao que se refere aos formatos de interação entre o teatro e comunidades possuem influência direta na conceituação proposta. Para saber mais (Nogueira, 2007).

${ }^{6}$ No período que antecede a ditadura do Estado Novo, Graciliano Ramos foi preso acusado de atividade subversiva. Mesmo sem nunca ter sido acusado formalmente passou mais de um ano encarcerado.

7 Alcatraz foi uma prisão localizada nos Estados Unidos da América, que esteve em funcionamento entre os anos de 1933 e 1963.
} 
No livro, Graciliano conta que assistiu uma peça de teatro feita pelos outros presos. O espetáculo zombava dos juízes e das penas impostas aos detentos da Colônia Penal. Sobre a transformação da prisão em ambiente teatral, o relato do Graciliano Ramos me fez lembrar quando eu vi vocês preparando o galpão para se apresentar aí em Serra Azul.

Alinharam perto dos cavaletes esses móveis toscos e em poucos minutos se formou um tablado, que mantas e lençóis ocultaram, seguros a cordas presas às paredes e às janelas. Num quarto de hora a prisão se mudou em teatro [...]. (Ramos, 1987, v. 2, p. 286).

Uma outra experiência do Teatro entre Presos foi realizada pelo Abdias do Nascimento no Carandiru. Ele foi um importante ativista dos direitos dos negros no Brasil, tendo sido preso em 1943 justamente por isto. Enquanto esteve preso, o Abdias chamou de Teatro do Sentenciado os espetáculos dele com os companheiros de cárcere. A professora Viviane Narvaes identificou seis peças montadas pelo Abdias do Nascimento no Carandiru: O dia de Colombo; Revista Penitenciária; Patrocínio e a República; Defensor Perpétuo do Brasil; Zé Bacoco; e O preguiçoso (Narvaes, 2016).

Novamente na Colônia Penal Candido Mendes, mas quase quarenta anos depois da prisão de Graciliano Ramos, William da Silva Lima, o professor, se juntou com os outros presos do "Caldeirão do Diabo" para montar um espetáculo teatral. Ele conta sobre a peça no livro 400 × 1: uma história do comando vermelho:

[...] decidimos não levar nossa atividade teatral para o campo dramático: - A situação aqui já é dramática...

Começamos com uma comédia, passada num manicômio, onde os loucos interpretavam os papéis que desejavam para si. Eu era um louco que escolhera viver um pistoleiro arrependido.

Fizemos muito sucesso. (Lima, 1991, p. 36-37).

Outra experiência de Teatro entre Presos foi feita por Carlos Alberto Libânio Christo, o Frei Betto. Ele montou dois espetáculos quando esteve preso na penitenciária de Presidente Venceslau. Frei Betto descreve assim o processo de criação teatral realizado na cadeia: 
Eu promovia os laboratórios. São ensaios improvisados. Eu pedia: "Companheiro, conte por que você veio parar na prisão, como é que foi exatamente o crime pelo qual você foi condenado" - e ele contava. Começava a representar o crime e fazia o papel de criminoso. Outro preso fazia o papel da vítima, outro da mulher da vítima, outro da polícia, do delegado, do investigador que torturou, do juiz... Depois, invertíamos os papéis. Era interessante quando aquele que tinha matado se via no lugar da vítima. Era o distanciamento que, pela primeira vez, ele tinha da própria atitude. Ele se via, inclusive, como juiz, tendo que decidir a pena. (Betto apud Concilio, 2016, p. 34).

Quando a gente se conheceu, você me falou sobre sua vontade de fazer faculdade de teatro quando saísse, lembra? Por isto, deixei por último o grupo de teatro Kriadaki, que foi formado em Bangu II e atualmente alguns dos atores estão na rua e seguem juntos, fazendo teatro.

Edson Sodré, um dos criadores do Kriadaki, começou a fazer teatro em outra cadeia, no complexo penitenciário da Frei Caneca. Há um projeto na Universidade Federal do Estado do Rio de Janeiro (UNIRIO) chamado Teatro em Prisões, no qual estudantes e professoras desenvolvem ações teatrais nas cadeias desde 1997. Mas, o interesse do Edson para começar a fazer teatro não era lá muito artístico. Ele soube que debaixo do auditório onde os encontros aconteciam passava uma tubulação, e o objetivo era fugir por ali. O plano não deu certo, um amigo dele foi pego com as ferramentas para cavar o "tatu". Mesmo assim, Sodré continuou participando do teatro. Ele tem uma fala bonita sobre isto, diz que o teatro foi "a maior fuga da vida dele”.

Depois de uns anos participando do teatro na Frei Caneca, Edson foi transferido para Bangu II. Mesmo estando em uma unidade muito mais violenta e quase sem projetos culturais (Sodré apud Moura, 2018), ele decidiu organizar um grupo de teatro com os companheiros de lá. Adriano Rodrigues de Oliveira foi um dos presos que topou participar. Adriano, que também está em liberdade e segue no grupo, deu uma entrevista e falou de como o Edson Sodré convenceu os companheiros a fazerem teatro: "Edson disse que, se montássemos um grupo de

\footnotetext{
8 Tatu é a expressão utilizada pela população carcerária para a escavação destinada a se evadir do presídio.
} 
teatro, iríamos fazer apresentação da peça nos presídios das mulheres. Era o sonho de qualquer preso". Me parece um ótimo argumento para fazer o pessoal participar do teatro, não acha?

Eles decidiram fazer a peça Os Saltimbancos, o texto é adaptado para o português ${ }^{9}$ pelo Chico Buarque, e conta a história de um grupo de animais que criam um conjunto musical e tentam se libertar da opressão dos humanos. Mas, quando o Adriano ouviu o nome da peça achou que era "assalto a banco", e não "Saltimbancos", como ele mesmo lembra:

Eu adorei a ideia. Fazer uma peça assaltando um banco? Que maravilha! [...] Chegou no dia seguinte, distribuíram os textos e eu não li nada sobre o assalto. Fui para grade avisar ao Sodré que não era possível. Cadê a peça assaltando um banco? (Moura, 2018).

As histórias do grupo Kriadaki parecem divertidas, até porque os atores contam como piada. Mas, o importante para mim foi conhecer um grupo de teatro formado na prisão que se mantém em atividade fora dela. Atualmente, o Edson Sodré é aluno da UNIRIO e estuda teatro. Olha como as coisas são: ele começou a fazer teatro na prisão com o pessoal da universidade, e depois de anos preso, se tornou aluno do curso de teatro na mesma universidade.

Estas experiências todas: Graciliano Ramos e do William da Silva Lima na colônia Penal Cândido Mendes, o Abdias do Nascimento no Carandiru, do Frei Betto, na penitenciária de Presidente Venceslau, o grupo Kriadaki em Bangu II e o Leandro aí na penitenciária "Serra Osso", digo... Serra Azul; me fizeram imaginar que muitas obras de arte são criadas dentro das 1412 instituições do sistema penal brasileiro (DEPEN, 2020), sem que nós, os que nunca tomamos um "bonde" com direção à cadeia, tomemos conhecimento delas.

Se existe um Teatro entre Presos, como chamar as experiências do Magno e de tantas outras pessoas que desenvolvem atividades teatrais com atores e atrizes aprisionados? Eu adotei o termo Teatro com Presos, para diferenciá-las do

\footnotetext{
${ }^{9}$ Adaptação do musical italiano / Musicanti, de Sérgio Bardotti e Luiz Henriquez Bacalov.
} 
Teatro entre Presos. Dentro desta categoria, consegui identificar 29 experiências, ${ }^{10}$ das quais doze seguiam em atividade em 2020.

\begin{tabular}{|c|c|}
\hline $\begin{array}{c}\text { ANO / PROJETO / COORDENADOR / } \\
\text { LOCAL }\end{array}$ & OBSERVAÇÕES \\
\hline $\begin{array}{l}\text { 1978-1982 - A Arte como Processo de } \\
\text { Recriação em Presidios } \\
\text { COORDENADORES: Maria Rita Freire } \\
\text { Costa; Elias Andreato. } \\
\text { Penitenciária Feminina da Capital. São } \\
\text { Paulo (SP) }\end{array}$ & $\begin{array}{l}\text { O projeto A Arte como Processo de Recriação em Presídios foi } \\
\text { desenvolvido na Penitenciária Feminina da Capital, São Paulo, SP. } \\
\text { A experiência foi interrompida devido à fuga de três presas antes } \\
\text { de uma apresentação no Centro Cultural São Paulo. No período } \\
\text { em que esteve ativo foram realizados cinco espetáculos: Criação } \\
\text { coletiva (1978), Favor não jogar amendoim (1979), Cela Forte } \\
\text { mulher (1980), Fala só de Malandragem (1982) e Nós de valor... nós } \\
\text { de fato (1983). Para saber mais: CONCíLIO (2006, p. 38-47). }\end{array}$ \\
\hline $\begin{array}{l}1980 \\
\text { COORDENADORES: Ruth Escobar; } \\
\text { Roberto Lage; Emílio Di Biasi; Luiz } \\
\text { Carlos Laborda. } \\
\text { Penitenciária do Estado. São Paulo } \\
\text { (SP) }\end{array}$ & $\begin{array}{l}\text { A experiência coordenada por Ruth Escobar e Roberto Lage na } \\
\text { Penitenciária do Estado realizou dois espetáculos: Aqui há ordem } \\
\text { e progresso, dirigido por Roberto Lage e dramaturgia coletiva; e O } \\
\text { Alto do Burro de Belém (texto de Chico de Assis), com direção de } \\
\text { Emílio Di Biasi e Luiz Carlos Laborda. Após uma rebelião na } \\
\text { penitenciária do Estado, Ruth Escobar foi acusada de incitar os } \\
\text { presos contra os agentes e assim a equipe do projeto foi impedida } \\
\text { de entrar no presídio. Para saber mais (Concílio, } 2006 \text { p. 47-57); } \\
\text { (Riedel, 2010, p. 323-325). }\end{array}$ \\
\hline $\begin{array}{l}1984 \text { - } 2002 \text { / Teatro em Presidios; } \\
\text { Talentos Aprisionados. } \\
\text { COORDENADORAS: Sophia Bisilliat; } \\
\text { Inês Castro; FUNAP/SP. }\end{array}$ & $\begin{array}{l}\text { Sophia Bisilliat e Inês Castro iniciaram seu trabalho no Carandiru } \\
\text { através da FUNAP/SP com o projeto Teatro em Presídios, tendo } \\
\text { realizado diversos espetáculos teatrais com os presos. } \\
\text { Posteriormente, com o encerramento do projeto, Sophia seguiu } \\
\text { como voluntária no Carandiru até sua implosão em 2002. Com o } \\
\text { projeto Talentos Aprisionados, a atriz fomentou diversas atividades } \\
\text { culturais no presídio, tendo ainda auxiliado o grupo de Rap 509-E } \\
\text { a gravar seu primeiro álbum. O projeto também possibilitou que } \\
\text { Luis Alberto Mendes publicasse o livro: Memórias de um } \\
\text { sobrevivente, enquanto estava preso no Carandiru. Para saber } \\
\text { mais: (Sophia Bisilliat, et. Al. 2003). }\end{array}$ \\
\hline COORDENADOR: Paul Heritage. & $\begin{array}{l}\text { Paul Heritage à época desenvolvia projetos teatrais em prisões da } \\
\text { Inglaterra, a partir das técnicas teatrais desenvolvidas por Augusto } \\
\text { Boal. Vindo ao Brasil como professor visitante da Universidade de } \\
\text { Brasília, o diretor desenvolveu suas primeiras experiências no } \\
\text { complexo penitenciário da Papuda. O grupo teatral era composto } \\
\text { por homens e mulheres, tencionando uma das principais } \\
\text { estruturas do sistema penitenciário, que é a separação por gênero } \\
\text { das pessoas que se encontram presas. A primeira experiência }\end{array}$ \\
\hline
\end{tabular}

10 O quadro foi desenvolvido como parte integrante da tese de doutorado: O Teatro Amador a partir de dois $P(s)$, que tem defesa prevista para março de 2021. Ele apresenta projetos teatrais na prisão iniciados até o ano de 2017, e que envolvam pessoas adultas privadas de suas liberdades. 


\begin{tabular}{|c|c|}
\hline $\begin{array}{l}\text { Complexo Penitenciário da Papuda. } \\
\text { Brasília (DF). }\end{array}$ & $\begin{array}{l}\text { cênica desenvolvida por Heritage na Papuda versava sobre a } \\
\text { escravidão. Para saber mais: (Concílio 2006, p. 57-59). }\end{array}$ \\
\hline $\begin{array}{l}\text { 1995-2001 / Teatro na Prisão: Drama - } \\
\text { DST/AIDS; Drama - Direitos Humanos } \\
\text { Coordenadores: FUNAP; UNICAMP; } \\
\text { CTO; } \\
\text { Paul Heritage; James Thompson; } \\
\text { Jorge Spínola; (outros) Robson } \\
\text { Rusche } \\
35 \text { Unidades Prisionais do Estado de } \\
\text { São Paulo (SP) }\end{array}$ & $\begin{array}{l}\text { O projeto: Teatro na Prisão: Drama - DST/AIDS foi realizado pela } \\
\text { FUNAP/SP em convênio com a UNICAMP. Para sua efetivação, a } \\
\text { proposta contou com a colaboração de Paul Heritage e James } \\
\text { Thompson. O projeto foi implementado em } 35 \text { unidades prisionais } \\
\text { do estado de São Paulo. Posteriormente, o Centro do Teatro do } \\
\text { Oprimido (CTO) se tornou parceiro da FUNAP/SP. A mudança do } \\
\text { nome do projeto de Drama - DST/AIDS para Drama - Direitos } \\
\text { Humanos indica a transformação dos objetivos da experiência ao } \\
\text { longo dos anos. Para saber mais: (Concílio, 2006); (Rusche, 1997). }\end{array}$ \\
\hline $\begin{array}{l}\text { Coordenadores: Timótheo Porto; } \\
\text { Janilce Rodrigues; Iza Rodrigues Maia }\end{array}$ & $\begin{array}{l}\text { Através do convênio SEDF - FUNAP/DF, professores de diversas } \\
\text { áreas do conhecimento passaram a lecionar nos presídios do } \\
\text { Distrito Federal. Participando da iniciativa, os professores } \\
\text { Timótheo Porto, Janilce Rodrigues e Iza Rodrigues Maia } \\
\text { fomentaram ações teatrais com presos. Dentre as experiências de } \\
\text { Timótheo Porto com presos estão os espetáculos: As comédias } \\
\text { (1999), Hamlet Encarcerado (2005) e Romeu e Julieta (2019). O } \\
\text { diretor, que atualmente coordena o grupo Julietas Encarceradas, } \\
\text { cunhou o termo Teatro Silenciado para se referir a suas } \\
\text { experiências na Prisão. Para saber mais: Porto (2011); Borgo (2019). } \\
\text { Janilce Rodrigues lecionou por oito anos nos presídios do distrito } \\
\text { Federal, em } 2007 \text { montou com os presos o espetáculo } \\
\text { Gonzaguinha, que se apresentou em diversos locais fora do } \\
\text { presídio. Em 2019, após sua aposentadoria, Janilce publicou o livro } \\
\text { Teatro em Cadeado, uma experiência em Cela de Aula. Para saber } \\
\text { mais: Rodrigues (2019). As primeiras experiências teatrais de Iza } \\
\text { Maia com presos são de 2011, no ano seguinte a diretora monta o } \\
\text { grupo Entreato. Desde então já foram realizados diversos } \\
\text { espetáculos com presos, dentre os quais: Comédias da vida } \\
\text { privada, adaptado da obra de Luís Fernando Veríssimo, e O } \\
\text { Mendigo e o Magnata, texto de Rutinaldo Rodrigues Miranda } \\
\text { Batista Junior. Para saber mais ver: (Governo do Distrito Federal, } \\
\text { 2018). }\end{array}$ \\
\hline $\begin{array}{l}\text { 1997-Atual / Teatro na Prisão. } \\
\text { Coordenadoras: Maria de Lourdes; } \\
\text { Naylor Rocha; Natália Ribeiro Ficher; } \\
\text { Viviane Narvaes }\end{array}$ & $\begin{array}{l}\text { O projeto de extensão universitária Teatro na Prisão, desenvolvido } \\
\text { na Universidade Federal do Rio de Janeiro (UNIRIO), teve início a } \\
\text { partir de uma oficina ministrada por Paul Heritage para } \\
\text { professoras e estudantes da instituição. Este é o projeto advindo } \\
\text { da universidade mais longevo que tomamos conhecimento no } \\
\text { Brasil, pois ele segue em atividade. Uma interessante abordagem } \\
\text { do projeto é desenvolvida por Sérgio Kauffmann, que realiza } \\
\text { experiências teatrais com mulheres trans e travestis aprisionadas } \\
\text { na Penitenciária Masculina Evaristo de Moraes (Kauffmann, 2019). } \\
\text { Mais adiante voltaremos a tratar do projeto de extensão Teatro Na } \\
\text { prisão. Para saber mais (Fiche, 2009); (Rocha, 2006); (Fiche; } \\
\text { Norvaes, 2016). }\end{array}$ \\
\hline
\end{tabular}


1999-2016 / Reabilitando pela arte: Cultura de paz pela não Violência; Grupo de Teatro: Sem... Nexo Com... Plexo

COORDENADORES: Marcelo Felice; Luís Carlos Marquez

Complexo penitenciário Ênio Pinheiro, Porto Velho (RO)

2002-2006 / Teatro do Oprimido nas prisões

COORDENADORES: Centro do Teatro do Oprimido (CTO); Departamento Nacional do Preso (DEPEN).

Penitenciárias em dez estados brasileiros: RO, PI, RN, PE, DF, ES, MG, SP, MS e RS

2006 - atual / Grupos de teatro: Mulheres de Atenas e Confraria da Serra

Coordenador: Magno Bucci

Penitenciária Feminina de Ribeirão Preto; Penitenciária de Serra Azul I

2008 - 2009 / Processos Educativos Através do Teatro

Coordenadores: FUNAP/SP; Jorge Spínola; Micael Carmo Cortes Gomes (Outros).

Diversas penitenciárias do estado de São Paulo

2008-atual / Teatro no Cárcere

Adriana Campos

Penitenciária II "Dr. José Augusto César Salgado, Tremembé (SP)
O projeto Reabilitando pela arte: Cultura de paz pela não Violência culminou com a criação do grupo de teatro Sem... Nexo Com... Plexo, coordenado por Marcelo Felice no Complexo penitenciário Ênio Pinheiro, Porto Velho (RO). Foram realizados dois espetáculos pelo grupo: Bizarrus (1999), que por mais de uma década esteve em cartaz com mudanças na encenação e no elenco, e Aqui é o topo do mundo, levado ao palco em 2013. Para saber mais: (Junqueira, 2005).

Através do acordo de cooperação firmado entre o Departamento Penitenciário Nacional (DEPEN) e o Centro do Teatro do Oprimido (CTO), foi desenvolvido o projeto Teatro do Oprimido nas prisões, que alcançou Penitenciárias em dez estados brasileiros: RO, PI, RN, PE, DF, ES, MG, SP, MS e RS. Para saber mais (Sarapeck, 2018).

Magno Bucci iniciou suas práticas teatrais com presos na Penitenciária Feminina de Ribeirão Preto em 2006, quando formou o grupo Mulheres de Atenas. No ano seguinte o trabalho alcançou o presídio de Serra Azul I, onde foi criado o grupo Confraria da Serra. As experiências de Magno Bucci serão apresentadas em maiores detalhes posteriormente neste artigo.

Jorge Spínola, em conjunto com a FUNAP/SP, foi responsável pela reedição do projeto Processos Educativos Através do Teatro. Um dos objetivos do projeto era formar entre os presos monitores para atividades culturais. O projeto foi implantado em diversas penitenciárias do estado de São Paulo, sendo encerrado em 2010. Para saber mais (Gomes, 2012).

O projeto Teatro no Cárcere é coordenado pela assistente social Adriana Campos, diretora do Centro de Reintegração e Atendimento à Saúde da Penitenciária II de Tremembé. O projeto teve início no ano de 2008, estando inativo por um período e retornando em 2014. Anualmente são montados aproximadamente cinco espetáculos, preparados para datas comemorativas da penitenciária. O repertório é variado, com peças religiosas: O presépio e A Paixão de Cristo, ambas de 2014, sátiras de textos consagrados, como Romeu e Julieta, levado a cena em 2019, ou de temas variados, como o espetáculo O Circo, 


\begin{tabular}{|c|c|}
\hline & $\begin{array}{l}\text { montado como Show de variedades em que se revezavam em } \\
\text { cena palhaços, mágicos e malabaristas. Para saber mais: (PRÊMIO } \\
\text { INNOVARE, 2015); (Cruz, 2019a); (Cruz, 2019b). }\end{array}$ \\
\hline $\begin{array}{l}\text { 2009-2010 / Rebelião Cultural } \\
\text { Coordenadores. Integrantes do Grupo } \\
\text { Favela a } 4 \text { (F4): } \\
\text { Complexo Penitenciário de Bangu; } \\
\text { Penitenciária Feminina Talavera Bruce, } \\
\text { No Rio de Janeiro (RJ) }\end{array}$ & $\begin{array}{l}\text { O coletivo Favela a 4, também chamada de "F4" remete ao } \\
\text { trabalho em conjunto de quatro importantes organizações que } \\
\text { atuam nas favelas cariocas: Afroreggae; Grupo Nós do Morro; } \\
\text { Observatório de Favelas e Central Única das Favelas. Favela a } 4 \text { foi } \\
\text { responsável pelo projeto Rebelião Cultural. A experiência } \\
\text { estimulava diversas atividades culturais no Complexo } \\
\text { Penitenciário de Bangu, e na Penitenciária Feminina Talavera Bruce, } \\
\text { No Rio de Janeiro, RJ. Para saber mais (Araújo; Castro, 2010). }\end{array}$ \\
\hline $\begin{array}{l}\text { 2010-2012 / Libert(arte): A Busca de } \\
\text { uma Liberdade Artística } \\
\text { Coordenador: Emerson de Paula } \\
\text { Complexo Penitenciário de Ponte Nova } \\
\text { (MG). }\end{array}$ & $\begin{array}{l}\text { O projeto Libert(art) foi coordenado pelo professor Emerson de } \\
\text { Paula na cidade de Ponte Nova (MG). A experiência se iniciou a } \\
\text { partir de disciplinas ministradas na Universidade Federal de Ouro } \\
\text { Preto (Teatro no Ensino Profissionalizante; Estágio Supervisionado } \\
\text { 2), nas quais um grupo de estudantes passaram a desenvolver } \\
\text { ações teatrais com os presos do Complexo Penitenciário de Ponte } \\
\text { Nova (MG). O projeto fomentou atividades artísticas e teatrais com } \\
\text { as presas do Complexo, e para se estruturar buscou dialogar com } \\
\text { os anseios das detentas e dos profissionais que atuavam na } \\
\text { instituição (Paula, 2019). }\end{array}$ \\
\hline $\begin{array}{l}\text { 2010-2015? / Grupo de Teatro Vida } \\
\text { Nova } \\
\text { Fábio Alves Moreira }\end{array}$ & $\begin{array}{l}\text { O grupo de teatro Vida Nova foi criado por iniciativa de Fábio Alves } \\
\text { Moreira, dançarino do grupo Aruana e agente prisional da } \\
\text { Penitenciária José Maria Alkimin. A partir de } 2015 \text { não conseguimos } \\
\text { encontrar atividades teatrais realizadas pelo grupo, o que nos faz } \\
\text { supor que o projeto tenha se encerrado. Ao longo dos anos foram } \\
\text { apresentadas peças que abordavam temáticas como o uso de } \\
\text { drogas, bullying e direitos humanos. Em } 2015 \text { foi realizado o } \\
\text { espetáculo Vida Nova. Para saber mais: (Alvim, 2011); } \\
\text { (Roberta;2015). }\end{array}$ \\
\hline $\begin{array}{l}\text { 2010-atual / Projeto Corpos Indóceis \& } \\
\text { Mentes Livres } \\
\text { Coordenadora: Denise Carrascosa }\end{array}$ & $\begin{array}{l}\text { Denise Carrascosa é a coordenadora do projeto de extensão } \\
\text { Corpos Indóceis \& Mentes Livres, desenvolvido pela Universidade } \\
\text { Federal da Bahia no Conjunto Penal Feminino do Complexo } \\
\text { Penitenciário Lemos Brito, na cidade de Salvador, BA. A proposta } \\
\text { envolve diversas linguagens artísticas visando fomentar a } \\
\text { expressão das mulheres presas. Dada a diversidade de ações } \\
\text { desenvolvidas, o projeto conta com a participação da atriz Márcia } \\
\text { Lima; a poetiza Luciany Aparecida; Val Souza, dançarina e } \\
\text { performance e a cineasta Patrícia Freitas. Todas estas mulheres } \\
\text { que desenvolvem as atividades com as presas são negras e } \\
\text { ativistas. Em } 2017 \text { foi apresentada a performance Não Sou bicho, } \\
\text { sou mulher. Para saber mais: (Issa, 2018) }\end{array}$ \\
\hline $\begin{array}{l}2011 \text { - atual / Grupo de teatro: Do Lado } \\
\text { de Cá. }\end{array}$ & $\begin{array}{l}\text { O grupo de teatro Do Lado de Cá é coordenado por lgor } \\
\text { Nascimento, agente penitenciário; e conta com o apoio de } \\
\text { diversos voluntários e funcionários da penitenciária. Ao longo dos }\end{array}$ \\
\hline
\end{tabular}




\begin{tabular}{|c|c|}
\hline $\begin{array}{l}\text { Coordenadores: Igor Rocha; Valdinei } \\
\text { Araújo de Freitas; Jorge Spínola }\end{array}$ & $\begin{array}{l}\text { anos, já foram realizados mais de quinze espetáculos, dentre os } \\
\text { quais O dia que a casa caiu (2011); Correntes da Liberdade (2015); } \\
\text { Morte e vida Severina (2017) e O alquimista (2019). Para saber mais: } \\
\text { (Kastner, 2012); (Pestana, 2015); }\end{array}$ \\
\hline $\begin{array}{l}\text { Penitenciária Adriano Murrey } \\
\text { Guarulhos (SP) }\end{array}$ & \\
\hline $\begin{array}{l}\text { 2011-2012 / Projeto Como vai seu } \\
\text { mundo? } \\
\text { Coordenadores: Júlio Suñé; Dexter; } \\
\text { Instituto Crescer; Coletivo Peso; Dr. } \\
\text { Jaime Garcia Junior. } \\
\text { Presídio José Parada Neto - } \\
\text { Guarulhos (SP). }\end{array}$ & $\begin{array}{l}\text { Dexter, integrante do grupo de Rap 509-E foi um dos idealizadores } \\
\text { do projeto Como vai seu mundo? A proposta envolvia sarau de } \\
\text { poesias, aulas de música e teatro no presídio José Parada Neto. } \\
\text { Sua realização se deu por iniciativa do juiz de execução penal Dr. } \\
\text { Jaime Garcia Júnior, que buscou o apoio de Dexter, que em } 2010 \\
\text { se encontrava preso em regime semiaberto no presídio José } \\
\text { Parada Neto. O grupo de teatro foi coordenado por Júlio Suñe. Para } \\
\text { saber mais: (Angelo et al, 2013). }\end{array}$ \\
\hline $\begin{array}{l}\text { 2012-2017? / Projeto Penarte } \\
\text { Coordenador: Cláudio Viana; Ivo Adnil }\end{array}$ & $\begin{array}{l}\text { O projeto PENARTE, desenvolvido no Presídio Feminino da cidade } \\
\text { de Nossa Senhora de Socorro, região metropolitana de Aracaju } \\
\text { (SE) foi criado por iniciativa do poeta Cláudio Viana, então agente } \\
\text { penitenciário do presídio, e Ivo Adnil, à época presidente do } \\
\text { Sindicato dos Artistas de Sergipe. Indicamos o ano de } 2017 \text { como } \\
\text { possível término do grupo teatral a partir da última atualização das } \\
\text { mídias sociais mantidas pelo projeto. Alguns dos espetáculos } \\
\text { realizados foram: O dia que os cadeados se rebelaram (2012); AS } \\
\text { violetas são belas, as abelhas, violentas (2013); A Ironia de Deus } \\
\text { (2014). Para saber mais: (PINHEIRO, 2019); (Marques et al, 2015). }\end{array}$ \\
\hline $\begin{array}{l}\text { 2014-atual / Projeto Arbítrio: Teatro nas } \\
\text { penitenciárias de Manaus } \\
\text { Coordenadora: Annie Martins Afonso }\end{array}$ & $\begin{array}{l}\text { Annie Martins Afonso é a coordenadora do projeto de extensão } \\
\text { Arbitrio: Teatro nas penitenciárias de Manaus, desenvolvido pela } \\
\text { Universidade Estadual do Amazonas (UEA). A experiência, que tem } \\
\text { por base as técnicas do Teatro do Oprimido, já realizou diversas } \\
\text { experiências artísticas, dentre as quais: espetáculos de Teatro- } \\
\text { fórum sobre temas que afligem as pessoas encarceradas e a peça } \\
\text { O Sol vai Voltar (2016). Em 2015, durante a apresentação ocorrida } \\
\text { na Assembleia Legislativa do Estado do Amazonas, que fazia parte } \\
\text { da IV Conferência Estadual de Políticas para Mulheres, uma peça } \\
\text { de Teatro-fórum que tratava dos estupros e violências sofridos } \\
\text { pelas presas no momento da detenção foi interrompida por } \\
\text { policiais e agentes de segurança presentes, o que resultou na } \\
\text { suspensão temporária do projeto, que posteriormente foi } \\
\text { retomado. Para saber mais: (Martins, 2016). }\end{array}$ \\
\hline $\begin{array}{l}2014 \text { / Projeto Dialogando com a } \\
\text { Liberdade } \\
2017 \text { - } 2018 \text { / Reencontro com o } \\
\text { Presídio }\end{array}$ & $\begin{array}{l}\text { O projeto Dialogando com a Liberdade foi desenvolvido no ano de } \\
2014 \text { por cinco meses com as presas do Conjunto Penal Feminino } \\
\text { de Salvador (BA). O projeto foi realizado por iniciativa de Simone } \\
\text { Requião, que conseguiu aprovar sua proposta em um edital de }\end{array}$ \\
\hline
\end{tabular}




\begin{tabular}{|c|c|}
\hline $\begin{array}{l}\text { Conjunto Penal Feminino - Salvador } \\
\text { (BA) }\end{array}$ & $\begin{array}{l}\text { apoio da Fundação Cultural do Estado da Bahia. Antes desta } \\
\text { experiência, Simone já havia tido outras experiências teatrais com } \\
\text { presos e presas em presídios da Bahia. No ano de 2017, a artista } \\
\text { voltou ao sistema penitenciário com o projeto Reencontro com o } \\
\text { Presídio, como parte da pesquisa de mestrado realizado na } \\
\text { Universidade Federal da Bahia, e que resultou na dissertação: } \\
\text { "Prisão, Pistas e Encadeamentos: Uma Experiência de Teatro no } \\
\text { Conjunto Penal Feminino (CPF)" - Requião (2018) }\end{array}$ \\
\hline $\begin{array}{l}2016 \text { - } 2017 \text { / Grupo Teatral Atuantes } \\
\text { Coordenador: Valdeir Gomes de } \\
\text { Oliveira } \\
\text { Conjunto Pental de Juazeiro - Juazeiro } \\
\text { (BA) }\end{array}$ & $\begin{array}{l}\text { O grupo de Teatro Atuantes foi criado a partir das experiências } \\
\text { desenvolvidas por Valdeir Gomes de Oliveira, quando este era } \\
\text { estudante da Universidade Federal do Vale do São Francisco e } \\
\text { realizava estágio curricular do curso de Licenciatura em Ciências } \\
\text { Sociais. A experiência resultou no Trabalho de Conclusão de Curso: } \\
\text { "Narrativas de atuantes no conjunto penal de Juazeiro". A defesa } \\
\text { do referido estudo ocorreu no interior do Conjunto Penal de } \\
\text { Juazeiro e contou com a realização do espetáculo Histórias } \\
\text { Descortinadas, na qual atuaram dez detentos. Para saber mais: } \\
\text { (Oliveira, 2017). }\end{array}$ \\
\hline $\begin{array}{l}2016 \text { - atual / Grupo de teatro: } \\
\text { Mulheres de Aço e de Flores.; projeto } \\
\text { Espelho da Realidade. } \\
\text { Cooordenador: Valdsom Braga } \\
\text { Penitenciária Feminina do Piauí; } \\
\text { Presídio Irmão Guido. Teresina (PI). }\end{array}$ & $\begin{array}{l}\text { Desde 2016, Valdsom Braga desenvolve atividades teatrais em } \\
\text { presídios de Teresina (PI). A experiência resultou na criação do } \\
\text { grupo de teatro Mulheres de Flores e Aço, na Penitenciária } \\
\text { Feminina de Teresina. No ano seguinte, Valdsom passou a } \\
\text { coordenar o grupo Espelho da Realidade no presídio masculino } \\
\text { Irmão Guido. Dentre os espetáculos realizados pelo grupo } \\
\text { Mulheres de Aço e Flores estão: Cartas de Minha Vida (2016) e } \\
\text { Colcha de Retalhos (2017). O grupo Espelhos da Realidade já } \\
\text { apresentou, dentre outros: Justiça (2017), o musical Siga a Estrela } \\
\text { (2017), Os Pássaros que não Voam (2018). Para saber mais. (Braga, } \\
\text { 2016). }\end{array}$ \\
\hline $\begin{array}{l}\text { 2017- atual / Performance e direitos } \\
\text { humanos: discursos pela tolerância. } \\
\text { Coordenadora: Christina Gontijo } \\
\text { Fornaciari } \\
\text { A Associação de Proteção e } \\
\text { Assistência aos Condenados - APAC. } \\
\text { Viçosa (MG). }\end{array}$ & $\begin{array}{l}\text { O projeto de extensão universitária Performance e Direitos } \\
\text { Humanos: Discursos pela tolerância está vinculado à Universidade } \\
\text { Federal de Viçosa, sendo coordenado por Christina Gontijo } \\
\text { Fornaciari. A atividade é desenvolvida na sede da Associação de } \\
\text { Proteção e Assistência aos Condenados de Viçosa, e visa } \\
\text { desenvolver com os envolvidos práticas vinculadas à arte } \\
\text { contemporânea, principalmente à Performance. Para saber mais: } \\
\text { (Fornaciari et. al. 2018). }\end{array}$ \\
\hline $\begin{array}{l}\text { Centro de Recuperação Feminino. } \\
\text { Ananideua (PA). }\end{array}$ & $\begin{array}{l}\text { As aulas de teatro ministrada por Paulo Marat na penitenciária } \\
\text { feminina de Ananindeua/PA fizeram parte do projeto Leitura que } \\
\text { Liberta. A experiência resultou no espetáculo A bolsa amarela, de } \\
\text { Lygia Bojunga Nunes. Ainda em 2017, Marat estava ensaiando uma } \\
\text { nova peça no Centro de Recuperação, Encontros, Desencontros e } \\
\text { Peripécias. Mas a atividade foi suspensa, devido a incidentes } \\
\text { ocorridos nos presídios paraenses. Para saber mais: (Balieiro, } \\
\text { 2017). }\end{array}$ \\
\hline
\end{tabular}




\begin{tabular}{|c|c|}
\hline $\begin{array}{l}\text { Presídio Feminino de Florianópolis. } \\
\text { Florianópolis (SC) }\end{array}$ & $\begin{array}{l}\text { Vicente Concílio, coordenador do Coletivo de Teatro do Presídio } \\
\text { Feminino de Florianópolis, é um dos principais pesquisadores } \\
\text { brasileiros do teatro na prisão. Desde 2017, Vicente desenvolve } \\
\text { atividades teatrais na Presídio Feminino de Florianópolis. O projeto } \\
\text { faz parte da extensão universitária: Pedagogia do Teatro e } \\
\text { Processos de Criação; e do grupo de pesquisa: Infiltrações das } \\
\text { artes cênicas nos espaços de privação de liberdade. O Coletivo } \\
\text { apresentou em } 2018 \text { o exercício cênico Vulsh, durante da 2a Mostra } \\
\text { Laboral do Sistema Prisional Brasileiro, realizado em Florianópolis. } \\
\text { No ano de } 2019 \text { foi realizado o espetáculo Estendemos nossas } \\
\text { memórias ao Sol. Para saber mais: (Concílio; Vetori, 2019). }\end{array}$ \\
\hline $\begin{array}{l}\text { 2017-atual I Teatro e Inclusão: } \\
\text { Ressocialização Através da Arte } \\
\text { Coordenadores: Emerson de Paula; } \\
\text { Frederico de Carvalho } \\
\text { Instituto de Administração } \\
\text { Penitenciária do Amapá (IAPEN) - } \\
\text { Masculino e Feminino. Macapá (AP) }\end{array}$ & $\begin{array}{l}\text { O projeto de extensão universitária: Teatro e Inclusão: } \\
\text { Ressocialização Através da Arte é desenvolvido pela Universidade } \\
\text { Federal do Amapá (UNIFAP), sendo coordenado pelos professores } \\
\text { Emerson de Paula e Frederico de Carvalho. Os encontros ocorrem } \\
\text { na Escola Estadual São José, que está localizada no Instituto de } \\
\text { Administração Penitenciária do Amapá, e que atende tanto o } \\
\text { presídio Masculino como o Feminino de Macapá, sendo que o } \\
\text { projeto teatral se voltou para ambos os gêneros. Para saber mais: } \\
\text { (Paula et, al. 2019) }\end{array}$ \\
\hline
\end{tabular}

Este quadro é uma tentativa de fazer um levantamento das experiências teatrais que já foram desenvolvidas com presos no Brasil, mas sei que não consegui encontrar todas elas. Espero que uma vez publicado, outros pesquisadores possam contribuir para aumentar o registro das ações teatrais que ocorrem no sistema penal.

Mesmo não sendo completo, o levantamento me ajudou a compreender algumas das características do Teatro com pessoas aprisionadas ao longo do tempo. Em um primeiro momento, as pessoas se aproximavam do sistema penitenciário por iniciativa pessoal ou através de projetos desenvolvidos pelo poder público (com destaque àqueles desenvolvidos pela FUNAP/SP e o DEPEN). Com o tempo, as iniciativas do poder público foram ficando mais raras, ou simplesmente, deixaram de existir; mas aumentaram os projetos desenvolvidos por professores e alunos das universidades. 
Tenho vontade de falar mais sobre todas estas experiências, porque foi de grande aprendizagem conhecê-las e perceber que tem tanta gente realizando um trabalho dos mais significativos para a população carcerária. Mas, nesta cartaartigo não é possível realizar o aprofundamento neste sentido, porque quero ainda tratar das experiências de vocês aí em Serra Azul, e de como foi assistir à peça: A Viagem do Chico.

Antes de mudar de assunto, gostaria de chamar sua atenção para a característica de três das experiências que estão no quadro: Projeto Penarte, Grupo do Lado de Cá e Grupo de Teatro Vida Nova. Elas se diferenciam das outras por terem sido coordenadas por agentes penitenciários. Você me contou que quando conheceu o Magno, achou que ele trabalhava aí em Serra Azul I, e estranhou um agente ser professor de teatro na cadeia, lembra? Vou trazer o trecho da entrevista em que você diz isto:

Como eu era muito novo - porque eu vim preso com dezoito anos quando eu cheguei eu estava meio assim... tudo novidade para mim. Eu não sabia o que era cadeia, eu não sabia como eram as coisas. Aí eu vi ele. Para mim, ele era um rapaz aqui da unidade, tipo um funcionário, um agente. Eu fiquei meio naquela, será que é um agente que dá aula para a gente aqui? (Araújo, 2020).

Parece difícil de acreditar que o fazer teatral possa modificar, pelo menos um pouco, a relação entre agentes penitenciários e pessoas aprisionadas. Mas, isto de fato ocorreu com estes grupos. A partir destas experiências me veio uma pergunta, seriam elas pertencentes ao teatro entre presos? Uma vez que os agentes fazem parte do cotidiano da cadeia; ou do teatro com presos? Tendo em vista eles não pertencerem à população carcerária. Cheguei à conclusão de que não são nem uma coisa, e nem a outra. Tento explicar. Elas estão no limite entre as duas categorias que busquei descrever. Em estudos de teatro, a gente costuma dizer que experiências como estas, que se encontram em uma posição intermediária, são limítrofes ou fronteiriças.

Talvez você goste de saber que o Teatro em Presídio, coordenado pelo Magno aí na região metropolitana de Ribeirão Preto, é o segundo projeto mais antigo em 
atividade entre os que consegui encontrar, e o mais antigo realizado de forma autônoma, pois o trabalho acontece a partir do voluntariado dele, e não conta com nenhum apoio de instituições ou do governo.

O Magno começou na feminina em 2006, quando formou com as presas o grupo Mulheres de Atenas. Ele me contou que ir à prisão fazer teatro significava um reinventar artístico, pois já estava: "[...] fazendo a mesma coisa a tanto tempo, pega um texto, faz o estudo do texto e põe em cena” (Bucci, 2020). O próprio Magno Bucci escreveu um artigo em que conta sobre o interesse dele no fazer teatral com as pessoas aprisionadas:

estou aqui porque tenho interesse em pessoas que continuam sonhando e aqui me parece um lugar onde se sonha muito. Acredito que aqui o sonhar acontece todo dia. Então eu estou aqui porque me interesso muito por essas pessoas (Bucci, 2007).

A troca que ocorre entre vocês parece ser uma das principais motivações para o trabalho se manter por tantos anos. Se por um lado, o Magno se dedica voluntariamente ao projeto, aportando seu conhecimento sobre teatro ao grupo; e talvez, fazendo o "sofrimento" ficar pelo menos um pouco "menos sofrido"; por outro, vocês possibilitam um fazer teatral significativo para ele, que se efetiva a partir de uma realidade que lhe é estranha.

A primeira peça do grupo Mulheres de Atenas foi Gran Circus Mulheres de Atenas. O fotógrafo Cesar Mulatti pode registrar uma das apresentações, que ocorreu dentro do raio. As fotos compuseram depois a exposição Liberdade em cena, e são excepcionais. 
Figuras 2, 3 e 4 - Gran Circus Mulheres de Atenas. Fotos: Cesar Mulatti
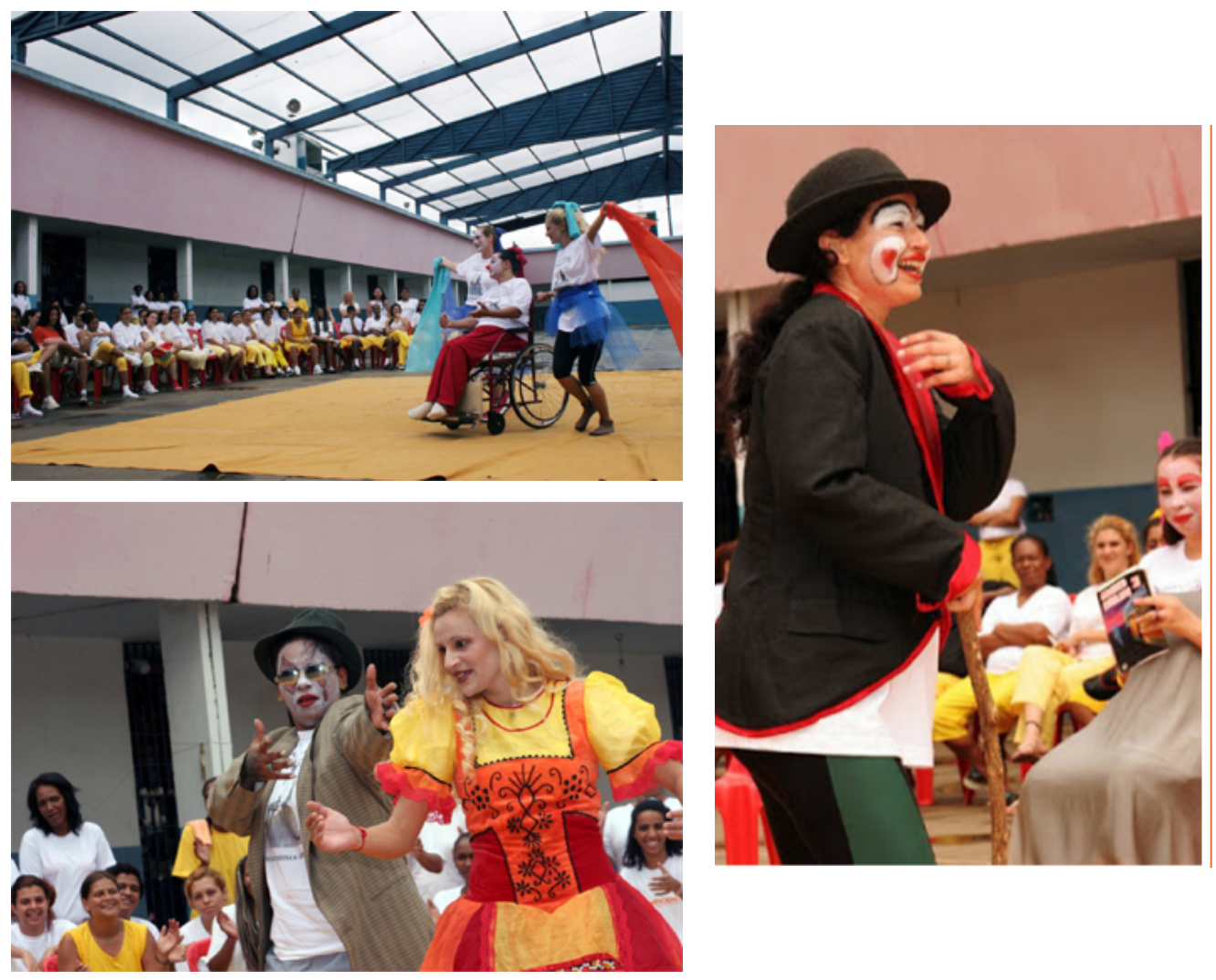

Em todos estes anos em que está em atividade, o grupo Mulheres de Atenas já realizou diversos espetáculos, mas gostaria de destacar o Olha o que eu vejo aí, que quadro de amarguras, porque esta foi à única vez que o Magno conseguiu levar uma peça feita na cadeia, para fora da prisão. As atrizes do grupo Mulheres de Atenas se apresentaram no teatro Santa Rosa em 30 de junho de 2017, na cidade de Ribeirão Preto.

O espetáculo foi criado a partir de histórias contadas por empregadas domésticas sobre as violências que elas sofriam enquanto estavam no trabalho. Tinha todo tipo de humilhação: patroa que chamava a empregada de gorda e não a deixava comer nada enquanto estava trabalhando, outra que falava para a empregada levar os "restos" de comida para casa, já que os filhos dela eram pobres e nunca deviam ter comido nada bom, e por aí vai. 
Vou trazer a última cena da peça, em que uma patroa está entrevistando uma candidata para realizar o serviço doméstico em sua casa. Durante as perguntas da patroa, a candidata ao emprego vai se abaixando até ficar com os joelhos e as mãos no chão.

Figura 5: Espetáculo Olha o que eu vejo aí, que quadro de amarguras. Imagem captada pela TV UNAERP em gravação audiovisual

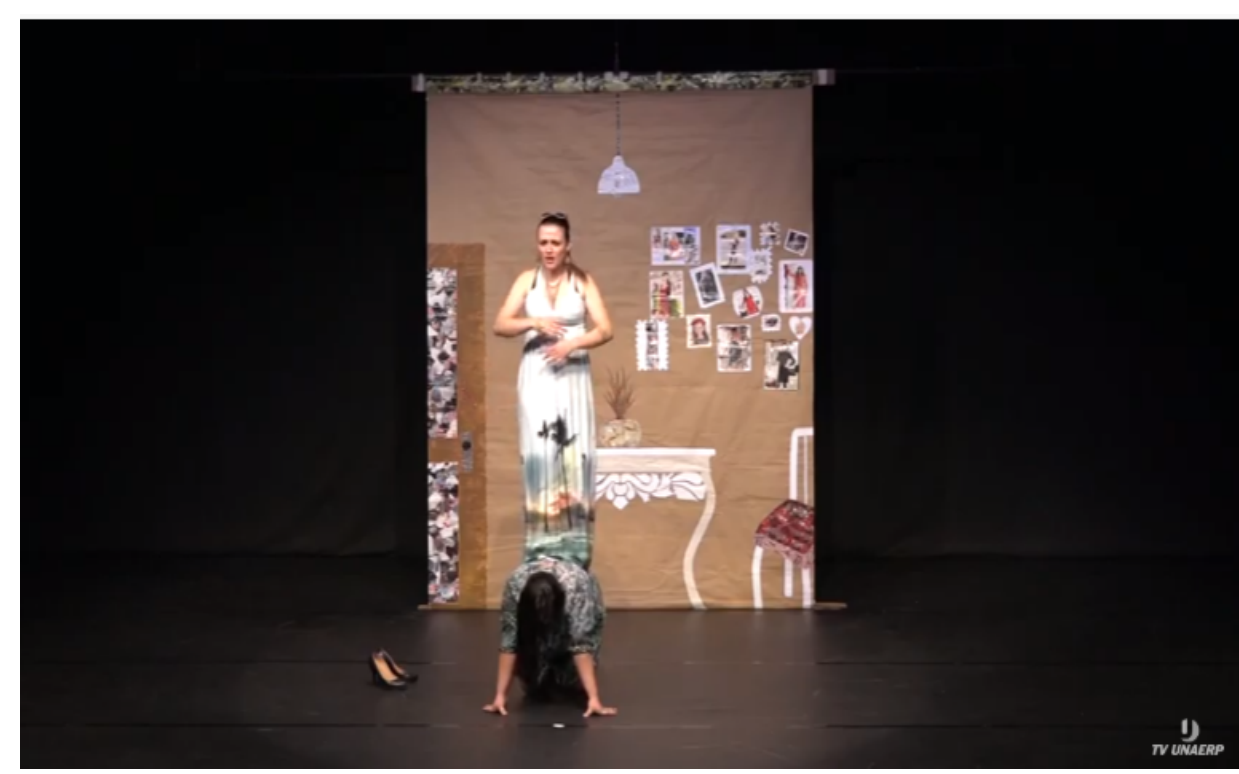

A patroa então sobe em suas costas, enquanto faz um discurso impactante ao expor sua "expectativa" em relação ao trabalho a ser executado.

Porque eu preciso de uma empregada para limpar todos os banheiros, para limpar a merda que meu filho faz todo o santo dia. Para limpar a merda que meu marido faz também. Para limpar a merda que meus amigos que vem lá de fora fazem também. Eles vem aqui só para fazer merda, merda e merda, em cima de merda! Preciso também que você limpe o canil, limpar as merdas que meus cães fazem todos os dias. Você está me ouvindo? Ou não? Porque parece que está um pouco difícil para você. Eu preciso de uma pessoa para limpar a merda, a merda que este Brasil tá também! Eu já não aguento mais tanta merda! Esta merda de sociedade! Esta merda de injustiça! (Grupo Mulheres de Atenas, 2017)11.

${ }^{11}$ Texto transcrito de gravação audiovisual realizada pela TV UNAERP e disponível em: https://www.youtube.com/watch?v=j47n8JZHJiQ\&feature=youtu.be. 
Já o grupo de vocês, Confraria da Serra, iniciou em 2007, um ano depois do Mulheres de Atenas. O diretor do Presídio Feminino de Ribeirão Preto, Reginaldo Neves Araújo, e a responsável pelo setor de recuperação e reabilitação, Carolina Zanirato, foram transferidos para a Penitenciária de Serra Azul I, e convidaram o Magno para estender o trabalho da feminina para a masculina. (Bucci, 2019).

Ao longo dos anos, um tema se tornou recorrente nos espetáculos realizados pelo grupo Confraria da Serra: o preconceito sofrido pelo egresso do sistema prisional. Em O caso da padaria (2009), Grande Hotel Torre de Babel (2010) e Nem Tudo é o que parece (2017) algo de valor desaparece, e a suspeita recai sobre a pessoa que já passou pela prisão. Mas no final, se descobre um mal entendido, o objeto reaparece e o ex-presidiário tinha sido acusado injustamente. Consegui encontrar dois motivos para que exista uma repetição temática nestas peças. O primeiro tem relação com o processo de criação que o Magno desenvolveu com vocês na maioria dos espetáculos, em que os atores e atrizes escolhem sobre o que querem falar, e as cenas são criadas através de improvisações que vão compondo a peça. A segunda, que está vinculada a anterior, é a rotatividade dos integrantes, que faz com que cada espetáculo conte com atores diferentes, e que muitas vezes, os novos componentes dos grupos não conhecem as criações realizadas pelos anteriores. Este é um aspecto importante para se compreender as experiências teatrais realizada por artistas aprisionados, pois se torna estrutural que o grupo esteja constantemente se renovando, na melhor das hipóteses, isto ocorre quando a liberdade "canta", mas também existem outros motivos, como uma punição disciplinar ou a transferência para outro presídio.

Mesmo conhecendo diversos espetáculos feitos pelo grupo Confraria da Serra, vou contar um pouco sobre $A$ Viagem do Chico porque foi o único que pude assistir, e companheiro, para começar, tenho que dizer: vocês arrebentaram nas duas apresentações que assisti. 
Figura 6 - Cartaz realizado por Bruno Araújo do espetáculo: A viagem do Chico. Foto: Zeca Nosé

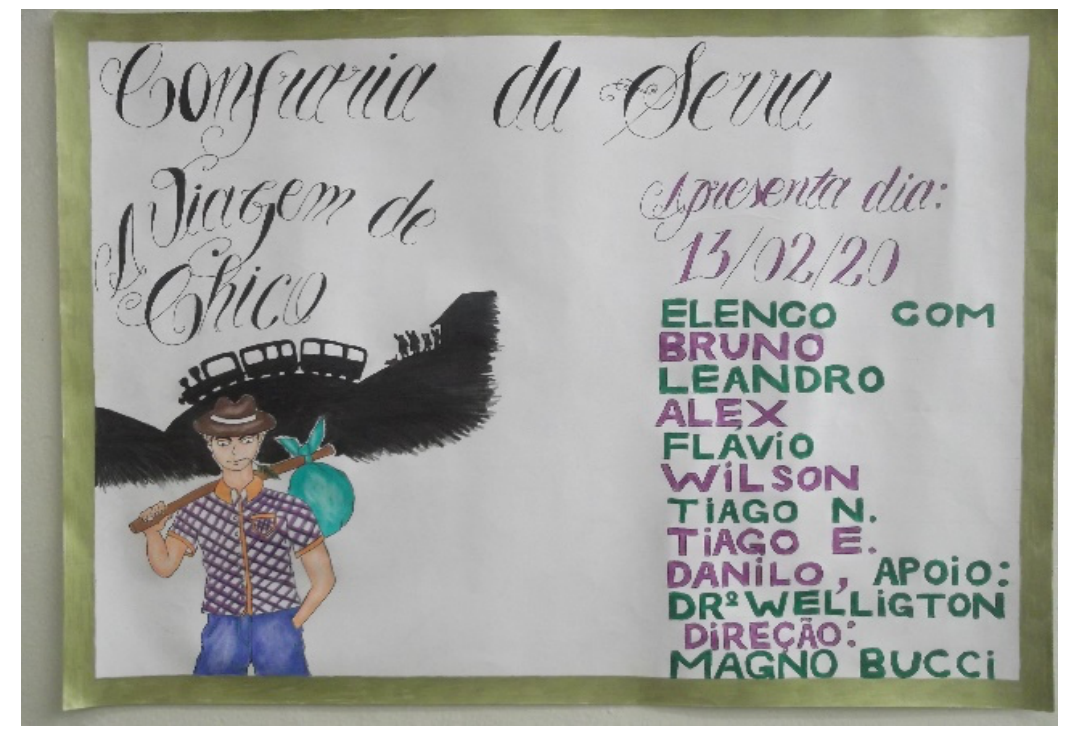

O primeiro aspecto impactante da peça para mim foi em relação aos espectadores. Vocês arrumaram as cadeiras deixando um corredor no meio. À direita, se sentaram apenas as pessoas que vestiam calça bege, camisa branca e chinelo, ou seja, os espectadores que estavam presos. Já os da esquerda vestiam, quase todos: calça jeans, sapatos e camisas pretas, uniforme dos agentes penitenciários.

Antes do espetáculo, tanto os presos como os agentes conversavam em voz baixa. Este era o clima que senti antes de começar a peça, tensão e sussurros. Sendo assim, a transformação que aconteceu depois é de estrema importância e não sei se sou capaz de traduzir em palavras. Logo na primeira cena de $A$ Viagem do Chico, entravam você e o Flávio, interpretando a Mãe e a Avó do Chico. A resposta do público foi imediata ao perceberem que vocês representavam personagens femininas. À direita ouviam-se gargalhadas, a melhor recompensa que um ator pode receber do público quando busca fazê-lo rir. Na esquerda, notei as expressões dos funcionários mudando, o olhar vigilante foi dando lugar a uma expressão mais amena. Me arrisco a dizer que, mesmo de forma contida, esta parcela do público também estava se divertindo.

Estando baseada na revista em quadrinhos do Chico Bento, a peça apresenta 
logo no início a história que será narrada, em que Chico quer sair do interior e ir para a cidade, mas a família não permite. Mesmo sem apoio e com poucas condições financeiras, ele decide partir em busca de seu sonho.

Figura 7 - Personagens mãe e avó.

Foto: Zeca Nosé

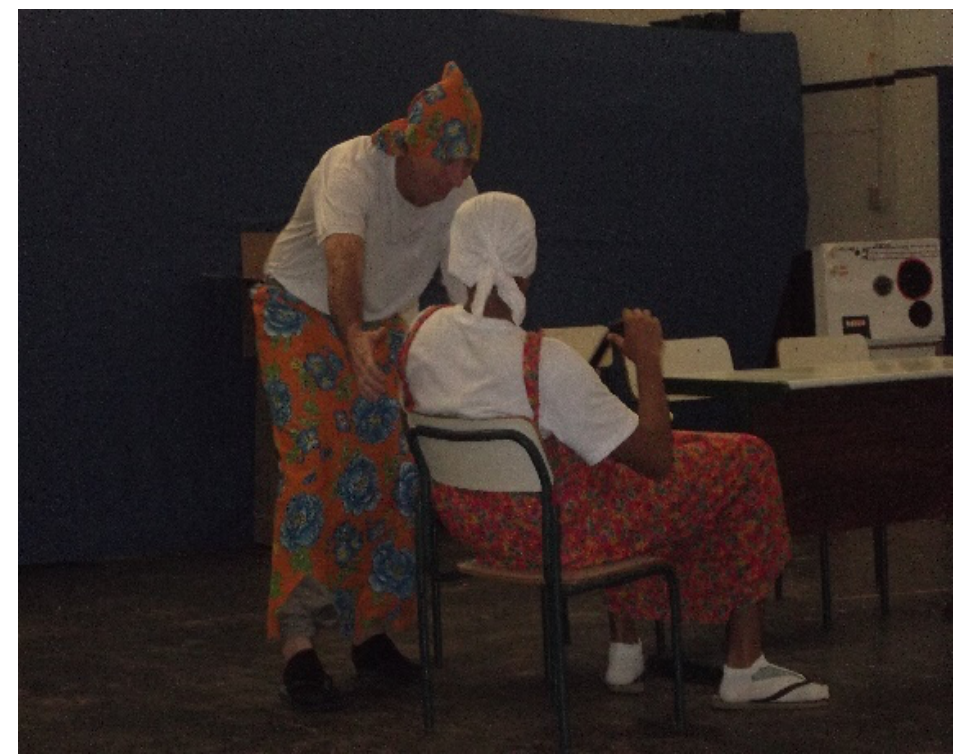

]Figura 8 - Cena Chico revela a família seu sonho de ir para a cidade. Foto: Zeca Nosé

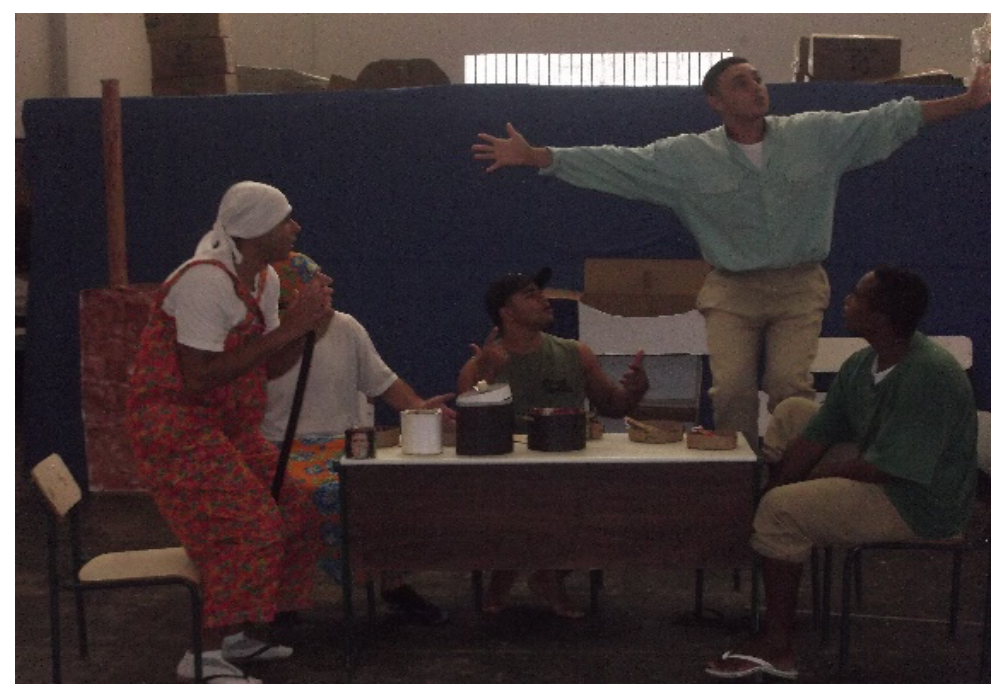


Para chegar à cidade, Chico toma um trem, mas não tem dinheiro para pagar a passagem e conta com o apoio do bilheteiro para poder realizar seu sonho. Na cena em que o Chico parte, vocês mantiveram o tom cômico já explorado. Assim vão embarcando no trem o ceguinho, que você representava, um pai com uma criança bagunceira e o Chico. Estes personagens eram cômicos, por isto me pareceu natural que o público risse deles, mas demorei para compreender por que a entrada do bilheteiro despertou uma reação imediata do público. Depois vocês me contaram que isto tinha ocorrido pelo bigode falso da personagem, e parte da graça estava relacionada à proibição por parte da instituição que os presos deixem crescer a barba e bigode.

Figura 9 Chico parte para a cidade Foto: Zeca Nosé

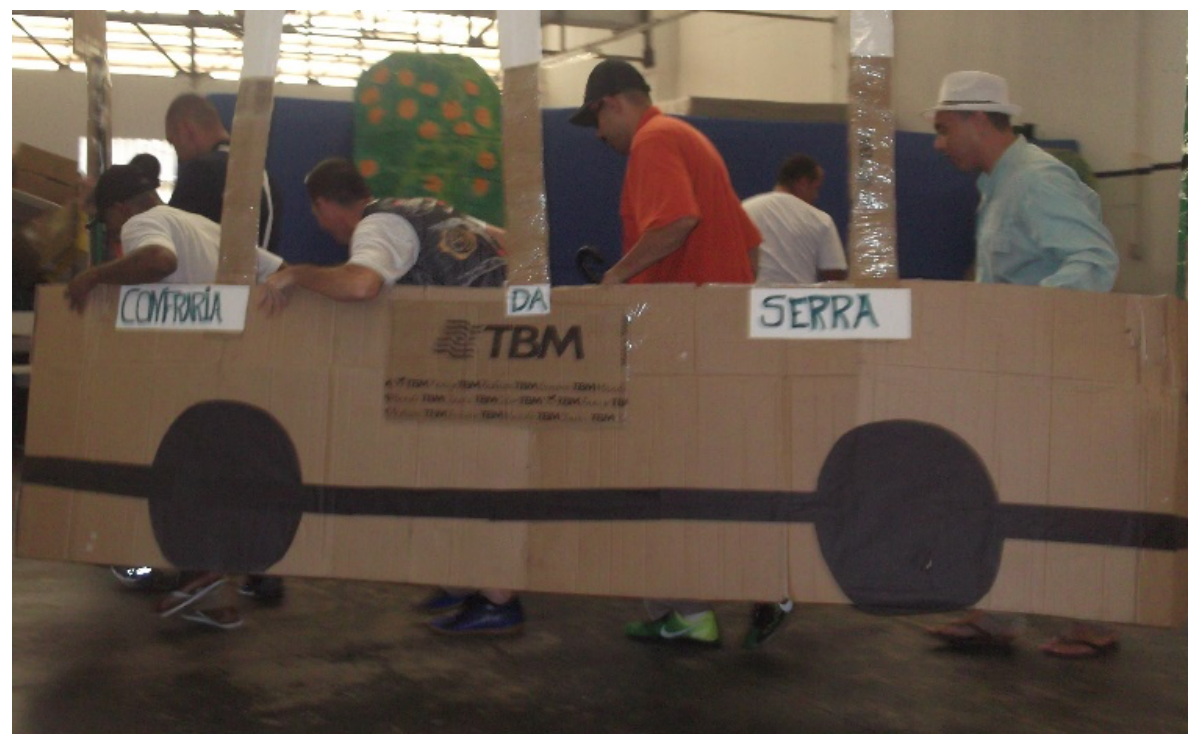

Uma vez na cidade, Chico viverá diversas adversidades, sendo enganado por um estelionatário; convidado para ser "piloto" de fuga em um roubo; para trabalhar com um traficante; humilhado por um empresário a quem pede ajuda, e por fim, roubado enquanto dormia no banco da praça. 
Figura 10 - Chico com estelionatário Foto: Zeca Nozé

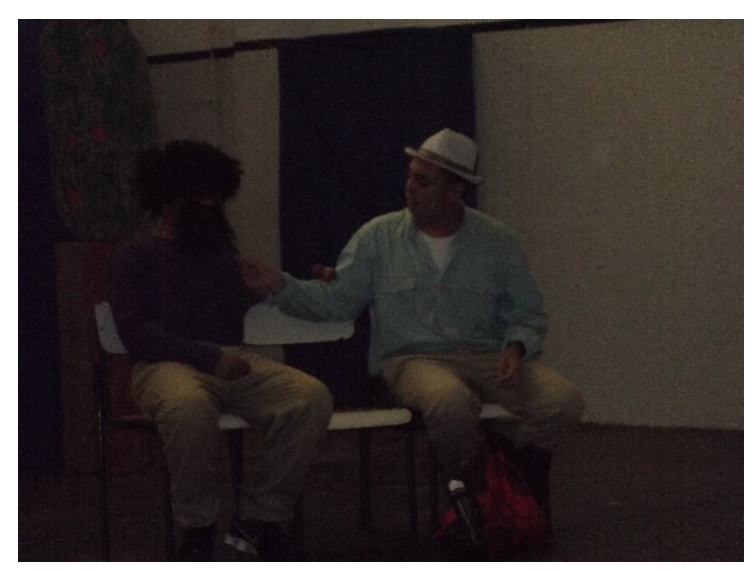

Figura 11 - Chico com empresário Foto: Zeca Nosé

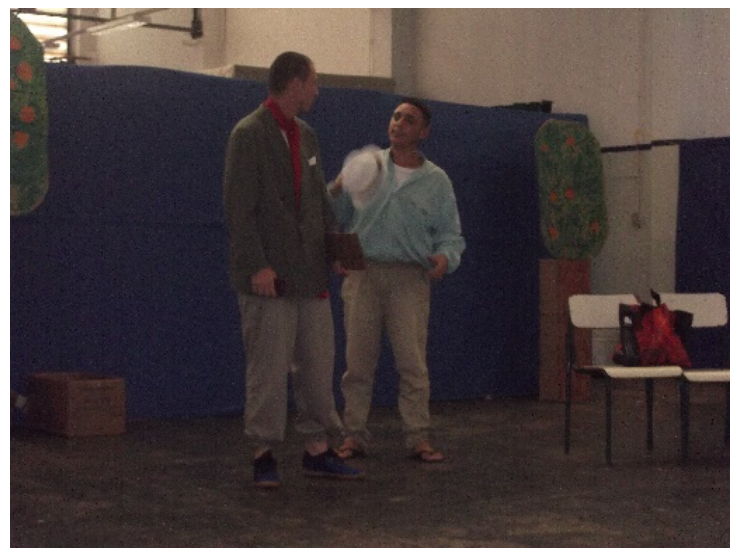

Figura 12 - Chico sendo roubado enquanto dormia Foto: Zeca Nosé

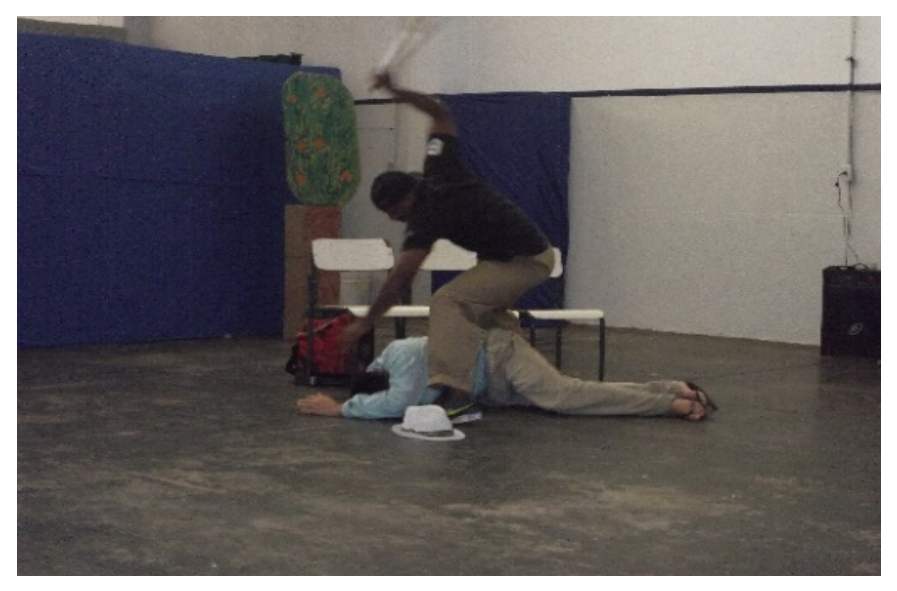

Vocês me contaram que quando estavam montando a peça, tinham que decidir o que aconteceria com o Chico depois dele ser roubado, e que vislumbravam inicialmente duas opções, ou ele voltava para o campo, ou se mantinha na cidade para tentar concretizar seu sonho. Mas a decisão tomada foi para mim algo de grande sensibilidade artística, pois vocês decidem não decidir, ou seja, a peça não tem um final definido do que aconteceu com o Chico depois do roubo. O Flávio Domingos explica o que aconteceu na entrevista dele:

Uma história com começo, meio, e sem o final, deixar o final para o público decidir do que eles entenderam a peça, que aí vem nós com nosso depoimento em cima da história do Chico, por que nossa história 
não tem ainda um fim aqui, dentro deste presídio, mas sim ela teve um começo, estamos no meio, e o fim? Depende de nós, então assim também, nós se inspira na história do Chico. (Domingos, 2020).

Acho extraordinário que a peça vá até o "meio" da história do Chico, vinculando com o momento que vocês atravessam, em que estar na cadeia não é o final, e este só será conhecido depois que vocês saírem daí. Como o Flávio menciona, após da cena do roubo vem o depoimento de vocês, que diante do público, um a um, trazem partes de suas vivencias, e encerram a fala com a frase: Eu sou Chico!

Figura 13 - Atores fazem depoimento que se encerra com a frase: Eu sou Chico. Foto: Zeca Nosé

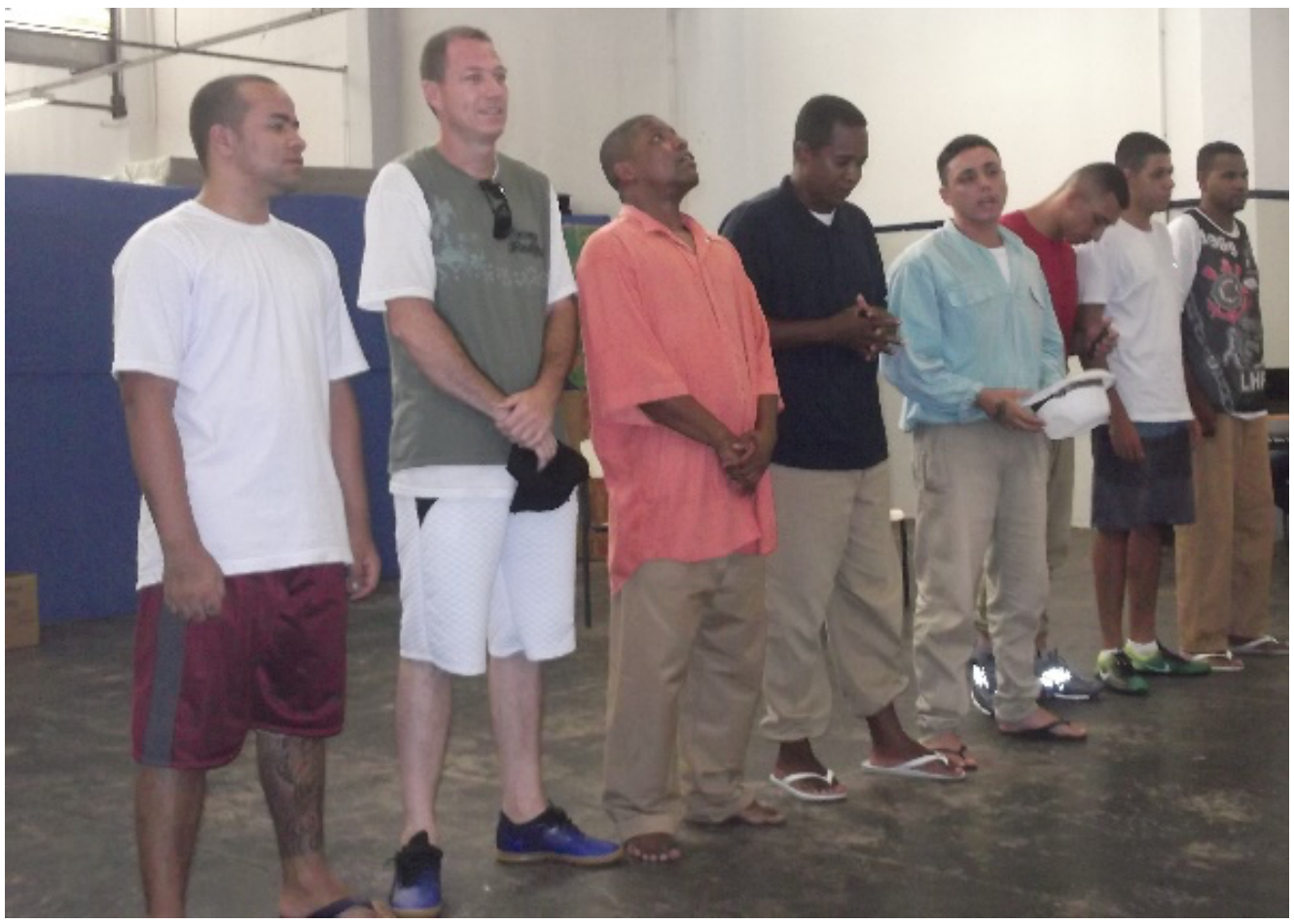

Foi perceptível para mim que o público ficou emocionado com o final do espetáculo e os relatos de vocês. Mas também tive a impressão de que os espectadores tentavam não demonstrar o que estavam sentindo, talvez por que a cadeia não seja o lugar ideal para transparecer alguns sentimentos.

Sabe Bruno, eu quis trazer o relato da peça de vocês e o levantamento das 
experiências teatrais que consegui encontrar na prisão, seja feita entre presos, seja feita com presos, porque estou construindo uma abordagem na pesquisa que privilegia a importância artística das peças feitas por atores e atrizes que não estão vinculados ao campo profissional do teatro. Quando a gente pensa no teatro feito por pessoas presas, existe uma tendência de reconhecê-las como experiências voltadas à educação. Certamente, existe um forte elemento pedagógico presente nelas. Você mesmo me disse que as experiências artísticas realizadas com o Magno te trouxeram reflexões importantes:

então eu comecei a imaginar, poxa, se na interpretação eu consigo viver isto, por que não aprender e usar isto na minha vida? Então eu vi, que o teatro, ele também pode ser usado como ferramenta para ressocializar as pessoas (Araújo, 2020).

Só que esta perspectiva pedagógica tende a existir em parte significativa das criações cênicas, sejam elas realizadas na cadeia, sejam nos mais luxuosos edifícios teatrais, pois quando fazemos um espetáculo no qual acreditamos, se expomos uma parte de nós mesmos em cena, dificilmente passamos imunes pela experiência. Um dos grandes mestres com quem tive contato se chamava Chico de Assis, que participou de pequenas e grandes revoluções do teatro brasileiro com o Teatro de Arena. O Chico costumava dizer em suas aulas que fazer teatro nos torna pessoas melhores, e que não conhecia energia mais potente do que o dia da estreia de um espetáculo, pois os envolvidos canalizam o melhor de si para efetivar o acontecimento artístico.

Então, mesmo existindo um processo de aprendizado, vocês também criam um objeto artístico único, que apenas pessoas presas seriam capazes de criar. Se um grupo profissional viesse de fora da cadeia e realizasse a mesma peça, para os mesmos espectadores, ele alcançaria um resultado diferente de vocês, e não quero dizer com isto se seria melhor ou pior, somente diferente. Ao presenciarem os companheiros de encarceramento em cena, os espectadores formam com este um vínculo que apenas pode ser construído desta forma. Um espetáculo feito por presos para os presos. 
Bruno, encerro esta carta-artigo agradecendo muito a oportunidade que vocês me deram de compartilhar do fazer teatral do grupo Confraria da Serra. Só não desejo vida longa ao grupo porque gostaria que as políticas de aprisionamento atuais não existissem, e por consequência, que este formato de experiência artística desaparecesse. Mas, no contexto atual e tendo em vista a possibilidade de redução de danos causados pelo sistema penal, que se proliferem mais e mais as práticas artísticas dentro da prisão. Muita força meu amigo, um grande abraço cheio de admiração e respeito.

\section{Referências}

ADORNO, Sérgio. Sistema Penitenciário no Brasil: problemas e desafios. Revista USP, São Paulo, v. 9, p. 65-78, 1991.

ALVIM, Carlos Eduardo. Liberdade para encenar e ensinar. Jornal Marco. Caderno Cidadania, 2011.

ANGELO, Damaris. Dexter, GOG e Coletivo Peso - Como vai Seu Mundo?. Soul Art. 4 nov. 2013.

ARAÚJO, Marianna; CASTRO, Vitor Monteiro de. Rebelião Cultural. Ed. Favela a 4, 2010.

ARAÚJO, Bruno. Entrevista concedida à Zeca Nosé em 13 fev. 2020. (Não publicada).

BALIEIRO, Tamaris. Detentas participam de oficina cênica para espetáculo teatral. SEAP/PA. Disponível em: http://www.seap.pa.gov.br/noticias/detentas-participamde-oficina-c\%C3\%AAnica-para-espet\%C3\%A1culo-teatral. Acesso em: 13 abr. 2020.

BISILLIAT, Sophia; BISILLIAT, Mauren; CARAMANTE, André. Aqui Dentro - Páginas de uma Memória: Carandiru. Ed. Imprensa Oficial, 2003.

BORGO, Nathalia. Educação ressocializa na penitenciária feminina do DF. SAP/DF. 2019. Disponivel em: http://www.educacao.df.gov.br/educacao-ressocializa-napenitenciaria-feminina-do-df/ Acesso em: 15 abr. 2020.

BRAGA, Valdsom. Teatro é usado como ferramenta de ressocialização de detentas no Piauí. 2016. Disponível em: https://180graus.com/artes-visuais/teatro-e-usadocomo-ferramenta-de-ressocializacao-de-detentas-no-piaui Acesso em: 12 abr. 2020. 
BUCCI, Magno. Teatro e Presidiárias: Além da Imaginação. Blog Magno Bucci, 2007. Disponivel em: http://mbucci.blogspot.com/p/teatro-e-presidiarias-alem-da.html. Acesso em: 18 abr. 2020.

BUCCI, Magno. Entrevista Concedida a Zeca Nosé em 21 out. 2019. (Não publicada).

CONCILIO, Vicente; VETORI, Caroline. Relato solto de uma oficina atrás das grades: Um Processo de Escrita Teatral no Presídio Feminino de Florianópolis. Revista IACA: Artes da Cena. Vol. II. n. 2, 2019.

CONCÍlIO, Vicente. Teatro e prisão: dilemas da liberdade artística em processos teatrais com população carcerária. 2006. Dissertação (Mestrado em Teatro) - Escola de Comunicações e Artes - Universidade de São Paulo, São Paulo, 2006.

CRUZ, Pierre. Presos apresentam peça teatral de Páscoa. Sap/SP. 2019a. Disponível em: http://www.sap.sp.gov.br/noticias/not1367.html. Acesso em: 04 maio 2020.

CRUZ, Pierre. Reeducandos de Tremembé fazem apresentação teatral em Jornada. SAP/SP. 2019. Disponível em: http://www.reintegracaosocial.sp.gov.br/noticia.php ?noticia=892. Acesso em: 04 maio 2020.

FICHE, Natália Ribeiro. Teatro na Prisão: trajetórias individuais e perspectivas coletivas. 2009. Dissertação (Mestrado em Teatro). Universidade Federal do Estado do Rio de Janeiro, 2009.

FORNACIARI, Christina Gontijo; SOARES, Rebeca Lima; PRETTE, Nailanita; SILVA, Inácio Andrade. Performance e Direitos Humanos: projetos de arte em instituições de cumprimento de pena. Revista Raízes e Rumos, Rio de Janeiro, v. 6, n. 1, p. 7-17, 2018.

DOMINGOS, Flávio. Entrevista concedida à Zeca Nosé em 13 fev. 2020. (Não Publicada).

RIEDEL, Erika. Emilio di Biasi: O Tempo e a Vida de um Aprendiz. Coleção Aplauso. São Paulo: Imprensa Oficial do Estado de São Paulo, 2010.

GOMES, MICAEL CARMO CÔRTES. Portas entreabertas - Em Busca de uma Educação Sensível a partir das Imagens, Espaços e Narrativas com TeatroEducação. 2012. Tese (Doutorado) - Universidade do Estado de São Paulo, São Paulo, 2012.

GRUPO MULHERES DE ATENAS. Espetáculo Olha o que eu vejo aí, que quadro de amarguras. Gravação audiovisual TV UNAERP, 2017. Disponível em: https://www.youtube.com/watch?v=j47n8JZHJiQ\&feature=youtu.be. Acesso em: 04 out. 2020.

Governo do Distrito Federal. PROJETO POLÍTICO-PEDAGÓGICO Centro Educacional 
01 de Brasília, 2018. p. 87-114. Disponível em http:// www.se.df.gov.br/wp-conteudo/uploads/2018/07/PPP-CED01Bras\%C3\%ADliaCREPP.pdf. Acesso em: 28 abr. 2020

HELEN SARAPECK, Helen. O SISTEMA PRISIONAL É PASSÍVEL PARA FISSURAS? Indagações e incertezas sobre o tema In: Teatro do Oprimido: práticas políticopedagógicas - "ensaios para a revolução. ANO 22 N 40, 2018.

JUNQUEIRA, Maria Hercília Rodrigues. A expansão do self de presidiários: encontro da psicologia com a arte e a profissão. São Paulo, 2005.

KASTNER. Guilherme. UM MUNDO MELHOR É POSSÍVEL In: psi jornal de psicologia, p. 16-17, 2012.

LIMA, William da Silva. Quatrocentos contra um: uma história do Comando Vermelho. Petrópolis: Vozes, 1991.

MARQUES, Verônica Texeira. et al. Cultura e arte: políticas públicas para reinserção social no presídio feminino sergipano. I Seminário Internacional de Pesquisa em Prisão. Faculdade de Direito da USP - São Paulo 02 out. 2015. Disponível em http://andhep.org.br/anais/arquivos/1seminario/GT2.pdf.

MARTINS, Annie Práticas teatrais na cidade de Manaus: dificuldades, desafios, conquistas e aprendizados dentro e fora da universidade. In: Anais XXVI Confaeb. POLITICAS PÚBLICAS E ENSINO DA ARTE, 2016.

MOURA, Caroline. Da prisão para os palcos: A história de três homens livres pelo teatro. Le Monde Diplomatique Brasil, 2018. Disponível em: https://diplomatique .org.br/da-prisao-para-os-palcos-a-historia-de-tres-homens-livres-pelo-teatro/

Acesso em: 17 abr. 2020.

NARVAES, Viviane. O Teatro do Sentenciado de Abdias Nascimento. Anais do XVII Encontro de História. ANPUH-Rio, 2016.

NARVAES, Viviane; FICHE, Natália Ribeiro. Teatro na prisão: limites, desafios e possiblidades. In: Teatro na Margem. Org. BALTAZER, Márcia Cristina, p. 133-158. São Paulo: HUCITEC, 2015.

OLIVEIRA, Valdeir Gomes. TEATRO NO CÁRCERE: narrativas de atuantes no Conjunto Penal de Juazeiro/BA. Trabalho de Conclusão de Curso; (Graduação em Ciências Sociais) - Universidade Federal do Vale do São Francisco, 2017.

PAULA, Emerson de; CARVALHO, Frederico Ferreira; SANTOS, Andressa da Silva; SILVA, Marcus Vinicius Sales. Teatro na Prisão: Relato de uma experiência de uma ação extensionista com os jogos teatrais na Escola Estadual São José - Macapá AP. Revista SAMAÚMA. p. 36-49, 2019.

PEREIRA, Leandro. Entrevista concedida à Zeca Nosé. 2020. (Não publicada). 
PESTANA, Sônia. Teatro na prisão liberta a emoção. Sap/sp. 2015. Disponível em: http://www.sap.sp.gov.br/noticias/not542.html. Acesso em: 03 maio 2020.

PINHEIRO, Karla. Campanha de conscientização as mulheres é lançada em presídio. INFONET. Disponível em https://infonet.com.br/noticias/cidade/campanha-deconscientizacao-as-mulheres-e-lancada-no-copemcan/. Acesso em: 30 abr. 2020.

PORTO, João Timótheo. ENCONTRAR O QUE NÃO PODE SER DITO: uma experiência na cena prisional com o Teatro do Silêncio. Artigo Científico para Especialização, 2011.

Premio Innovare. Aula teatral no sistema prisional do piaui. Edição XIV. 2017. Disponível em em: https://www.premioinnovare.com.br/pratica/aula-teatral-nosistema-prisional-do-piaui/print. Acesso em: 04 maio 2017.

Premio Innovare. Teatro no Cárcere um novo despertar. Edição VII, 2015. Disponível emhttps://www.premioinnovare.com.br/proposta/teatro-no-carcere-um-novodespertar-20150514114355856327/print. Acesso em: 04 maio 2020.

RAMOS, Graciliano. Memórias do cárcere. 23. ed. Rio de Janeiro: Record, 1987. 2 v.

ROBERTA, Paula. Detentos da penitenciária José Maria Alkmin encenam peça teatral. 2015 Disponivel em: http://www.seguranca.mg.gov.br/politica-deprivacidade/story/2701-detentosdapenitenciaria-jose-maria-alkmin-encenampeca-teatral. Acesso em: 03 maio 2020.

REQUIÃO, Simone. Prisão, Pistas e Encadeamentos: Uma experiência de Teatro no Conjunto Penal Feminino (CPF). 2020. Dissertação (Mestrado) - Universidade Federal da Bahia, Salvador, 2018.

ROCHA, Maria de Lourdes Naylor. Teatro na Prisão: A Dramaturgia da Prisão em Cena. 2006. Tese (Doutorado em Teatro) - Programa de Pós-Graduação em Teatro, Universidade Federal do Estado do Rio de Janeiro, 2006.

RODRIGUES, Janilce. Teatro em Cadeado, uma experiência em Cela de Aula. Distrito Federal. 2019.

RUSCHE, Robson Jesus; AMARAL, Lígia Assumpção. Teatro: gesto e atitude investigando processos educativos através de técnicas dramáticas, com um grupo de presidiários. 1997.Universidade de São Paulo, São Paulo, 1997.

SEMER, Marcelo; DIETER, Maurício Stegemann. Sentenciando tráfico: pânico moral e estado de negação formatando o papel dos juízes no grande encarceramento. 2019. Universidade de São Paulo, São Paulo, 2019. 
Recebido em: 07/10/2020

Aprovado em: 26/10/2020

Universidade do Estado de Santa Catarina - UDESC Programa de Pós-Graduação em Teatro - PPGT

Centro de Arte - CEART

Urdimento - Revista de Estudos em Artes Cênicas

Urdimento.ceart@udesc.br 